\title{
Review Article \\ Interaction of Hydrogen Sulfide with Oxygen Sensing under Hypoxia
}

\author{
Bo Wu, ${ }^{1}$ Huajian Teng, ${ }^{2}$ Li Zhang, ${ }^{1}$ Hong Li, ${ }^{1}$ Jing Li, ${ }^{3}$ Lina Wang, ${ }^{1}$ and Hongzhu Li ${ }^{1}$ \\ ${ }^{1}$ Department of Pathophysiology, Harbin Medical University, Harbin 150086, China \\ ${ }_{2}^{2}$ Joint Research Center for Bone and Joint Disease, Model Animal Research Center, Nanjing University, Nanjing 210093, China \\ ${ }^{3}$ Department of Geriatrics, The Second Affiliated Hospital of Harbin Medical University, Harbin 150086, China \\ Correspondence should be addressed to Bo Wu; wubow2012@aliyun.com
}

Received 30 November 2014; Accepted 22 January 2015

Academic Editor: Steven S. An

Copyright (C) 2015 Bo Wu et al. This is an open access article distributed under the Creative Commons Attribution License, which permits unrestricted use, distribution, and reproduction in any medium, provided the original work is properly cited.

Based on the discovery of endogenous $\mathrm{H}_{2} \mathrm{~S}$ production, many in depth studies show this gasotransmitter with a variety of physiological and pathological functions. Three enzymes, cystathionine $\beta$-synthase (CBS), cystathionine $\gamma$-lyase (CSE), and 3mercaptopyruvate sulfurtransferase (MST), are involved in enzymatic production of $\mathrm{H}_{2} \mathrm{~S}$. Emerging evidence has elucidated an important protective role of $\mathrm{H}_{2} \mathrm{~S}$ in hypoxic conditions in many mammalian systems. However, the mechanisms by which $\mathrm{H}_{2} \mathrm{~S}$ senses and responses to hypoxia are largely elusive. Hypoxia-inducible factors (HIFs) function as key regulators of oxygen sensing, activating target genes expression under hypoxia. Recent studies have shown that exogenous $\mathrm{H}_{2} \mathrm{~S}$ regulates HIF action in different patterns. The activation of carotid bodies is a sensitive and prompt response to hypoxia, rapidly enhancing general $\mathrm{O}_{2}$ supply. $\mathrm{H}_{2} \mathrm{~S}$ has been identified as an excitatory mediator of hypoxic sensing in the carotid bodies. This paper presents a brief review of the roles of these two pathways which contribute to hypoxic sensing of $\mathrm{H}_{2} \mathrm{~S}$.

\section{Introduction}

$\mathrm{H}_{2} \mathrm{~S}$ had been known mostly due to its unpleasant smell and fierce toxicity before its physiological importance was studied [1]. Production of $\mathrm{H}_{2} \mathrm{~S}$ in mammalian cells had been considered almost as a metabolic waste, until the physiological roles of this small molecular were elucidated in the central nervous system and the cardiovascular system nearly two decades ago $[2,3] . \mathrm{H}_{2} \mathrm{~S}$ is now identified as a well-known gasotransmitter which plays a critical role in both physiological regulation and pathophysiological processes of different mammalian tissues $[4,5]$. Endogenous $\mathrm{H}_{2} \mathrm{~S}$ levels have been reported in different mammalian systems, ranging from 50 to $160 \mu \mathrm{M}[6,7]$. The enzymatic production of endogenous $\mathrm{H}_{2} \mathrm{~S}$ were identified, mostly composed of cystathionine $\beta$-synthase (CBS) [8-10], cystathionine $\gamma$-lyase (CSE) [11-13], and 3-mercaptopyruvate sulfurtransferase (MST) [14-16].

$\mathrm{H}_{2} \mathrm{~S}$ and oxygen $\left(\mathrm{O}_{2}\right)$ are mutually exclusive on the Earth. During the Permian period, the depletion of oxygen and accumulation of $\mathrm{H}_{2} \mathrm{~S}$ in the oceans and the air caused great extinctions of more than 90 percent of life species [1, 17]. Physicochemical reactions in living cells require enough molecular oxygen $\mathrm{O}_{2}$ for essential metabolic processes. $\mathrm{O}_{2}$ serves as the terminal electron acceptor in the system of oxidative phosphorylation which produces high-energy phosphate bond in ATP $[18,19]$. Insufficient oxygen supply to tissues, organs, or cells constitutes hypoxia. Hypoxia is evoked by several kinds of causes which all lead to oxygenpartial-pressure $\left(\mathrm{PO}_{2}\right)$ in arterial blood less than $40 \mathrm{~mm} \mathrm{Hg}$ $[19,20]$. Several lines of evidence point to an important protective role of $\mathrm{H}_{2} \mathrm{~S}$ in hypoxic conditions. However, the mechanisms by which $\mathrm{H}_{2} \mathrm{~S}$ senses and responses to hypoxia are largely elusive. A master regulator of hypoxia in mammalian cells is hypoxia-inducible factor-1 (HIF-1), which activates the transcription of $>100$ target genes under hypoxic contexts [18, 21]. HIF-1 is involved in $\mathrm{H}_{2} \mathrm{~S}$-mediated angiogenesis under hypoxia [22, 23]. With the remarkable sensitivity and the prompt speed to response to hypoxia, the carotid bodies play a unique role in $\mathrm{O}_{2}$ sensing $[24,25]$. It has been shown that $\mathrm{H}_{2} \mathrm{~S}$ is involved in the regulation of 


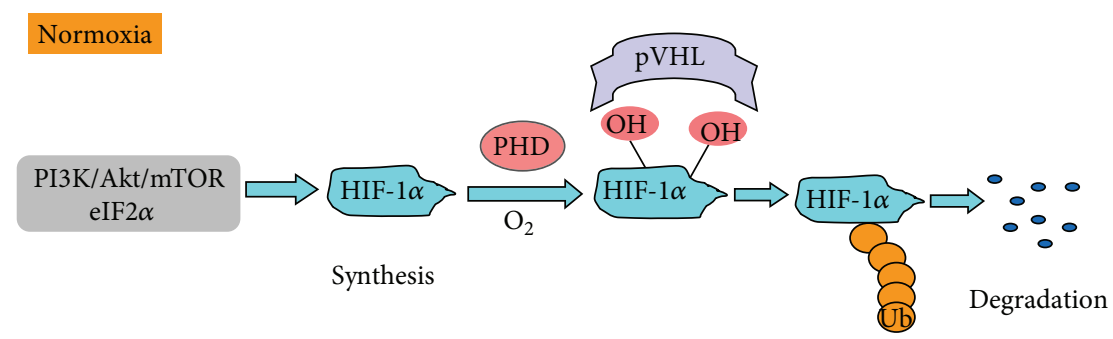

(a)

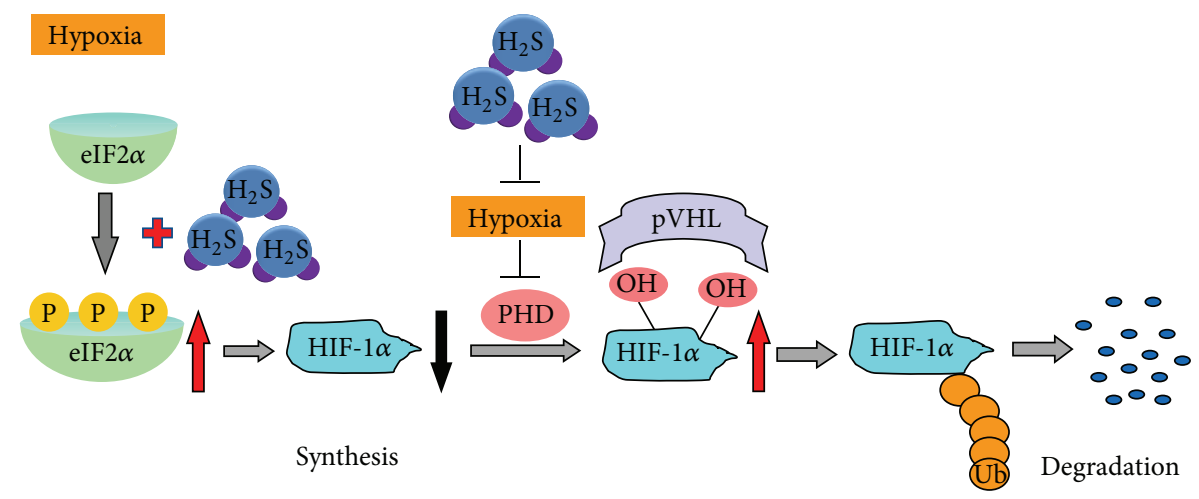

(b)

Figure 1: Pathways regulating HIF- $1 \alpha$ synthesis/degradation under normoxia and schematic illustration of $\mathrm{H}_{2} \mathrm{~S}$ effects on HIF- $1 \alpha$ accumulation under hypoxia. (a) HIF- $1 \alpha$ protein translation under normoxia is mainly dependent on activation of the PtdIns3K-Akt mammalian target of rapamycin (mTOR). HIF- $1 \alpha$ is hydroxylated by the prolyl hydroxylase (PHD) under normoxia. Hydroxylated HIF- $1 \alpha$ is then bound by the von Hippel Lindau protein (pVHL). This complex in turn recruits a ubiquitin ligase that targets HIF-1 $\alpha$ for its proteasomal degradation. (b) Under hypoxia, $\mathrm{H}_{2} \mathrm{~S}$ induces phosphorylation of translation initiation factor $2 \alpha$ (eIF $2 \alpha$ ). Phosphorylated eIF $2 \alpha$ inhibits HIF$1 \alpha$ translation. In addition, $\mathrm{H}_{2} \mathrm{~S}$ decreases cellular oxygen $\left(\mathrm{O}_{2}\right)$ consumption under hypoxia and reverses hypoxia-induced inhibition of PHD activity. Thus, $\mathrm{H}_{2} \mathrm{~S}$ enhances degradation of HIF- $1 \alpha$. Abbreviations: Ub, ubiquitin.

sensory activity in the carotid bodies [26, 27]. In genetically distinct rat models, variations in endogenous $\mathrm{H}_{2} \mathrm{~S}$ levels have been reported to be closely correlated with variations of carotid body $\mathrm{O}_{2}$ sensing in both hypoxia-induced pulmonary edema and essential hypertension [28]. In this paper, we review physiological responses of $\mathrm{H}_{2} \mathrm{~S}$ to hypoxia and focus particularly on the regulating effects of $\mathrm{H}_{2} \mathrm{~S}$ on HIF-1 action and the $\mathrm{O}_{2}$ sensing role of $\mathrm{H}_{2} \mathrm{~S}$ in the carotid bodies.

\section{2. $\mathrm{H}_{2} \mathrm{~S}$ and HIF-1 under Hypoxia}

2.1. Hypoxia and Hypoxia-Inducible Factor-1. HIF-1 was first identified as the protein responsible for the hypoxiaevoked transcription of erythropoietin [29, 30]. HIF-1 is a heterodimer consisting of the inducibly regulated HIF- $1 \alpha$ subunits and the constitutively expressed HIF-1 $\beta$ subunits [31]. Since the expression of HIF-1 $\beta$ is abundant in cells, HIF- $1 \alpha$ determines the protein level and the transcriptional activity of HIF-1 [21]. The HIF-1 heterodimer combines with the hypoxia-responsive element in target genes, thus enhancing target genes transcription [21].

Under normoxic conditions, although continuously transcribed and translated, the protein levels of HIF- $1 \alpha$ are hard to be detected in normal cells due to HIF- $1 \alpha$ protein fast degradation. Tow specific proline residues within the oxygen-dependent degradation (ODD) domain in HIF- $1 \alpha$ are hydroxylated by the prolyl hydroxylase (PHD) under normoxia. Hydroxylated HIF- $1 \alpha$ is then bound by the von Hippel Lindau protein (VHL) [32]. This complex in turn recruits a ubiquitin ligase that targets HIF- $1 \alpha$ for its proteasomal degradation [33] (Figure 1). PHD activity is inhibited under hypoxic conditions, thus resulting in HIF-1 $\alpha$ stabilization. Other pathways and regulators are also involved in HIF- $1 \alpha$ degradation [21].

Compared with the accumulated studies on HIF-1 $\alpha$ degradation, translational control of stress-survival protein HIF- $1 \alpha$ under hypoxia is far more beyond our understanding. HIF- $1 \alpha$ protein translation under normoxia is dependent on activation of the PtdIns 3 K-Akt mammalian target of rapamycin (mTOR) and the mitogen-activated protein kinases (MAPK) pathways [20, 21]. Under hypoxia-induced stress, phosphorylation of the translation initiation factor $2 \alpha(\mathrm{eIF} 2 \alpha)$ and inhibition of mTORC1 activity have been suggested to account for HIF- $1 \alpha$ protein expression inhibition [21] (Figure 1). Certain antitumour compounds which inhibit HIF- $1 \alpha$ translation contribute to eIF $2 \alpha$ phosphorylation [34, 35]. There is evidence that other factors are involved in HIF$1 \alpha$ translation regulation, that is, studies on the $5^{\prime} \mathrm{UTR}$ of HIF$1 \alpha$ which contains an internal ribosome-entry-site [21].

2.2. Effects of $\mathrm{H}_{2} \mathrm{~S}$ on HIF-1 Accumulation. Nitric oxide (NO), the first identified gasotransmitter, has been demonstrated 
to affect HIF-1 action [36, 37]. An early report showed that NO donors inhibited HIF-1 action under both hypoxia and hypoxia-mimetic conditions [36]. In later studies, by overexpressing the human iNOS to increase endogenous NO production, NO was shown to enhance HIF-1 protein accumulation and its activity [37]. The second gasotransmitter carbon monoxide (CO) has also been shown to regulate HIF-1 protein levels and activity in certain contexts [38]. A series of recent studies showed that $\mathrm{H}_{2} \mathrm{~S}$, like $\mathrm{NO}$ and $\mathrm{CO}$, plays an important role in the regulation of HIF-1 function under hypoxia. Caenorhabditis elegans (C. elegans) is an attractive model for hypoxia relative research [6]. This animal model was used to study the influence of $\mathrm{H}_{2} \mathrm{~S}$ on HIF-1. In C. elegans, the EGg laying defective- (EGL-) 9 is responsible for HIF-1 hydroxylation [39]. HIF-1 was closely correlated with increased tolerance of $\mathrm{H}_{2} \mathrm{~S}$ exposure in $\mathrm{C}$. elegans [39]. Animals with the HIF-1 null mutation did not survive from exposure to only $15 \mathrm{ppm}_{2} \mathrm{~S}$, while wild-type worms survived with high viability even exposure to $50 \mathrm{ppm}$ $\mathrm{H}_{2} \mathrm{~S}$ [39]. Mutations in either EGL-9 or VHL-1 induced an overabundance of HIF-1, which caused animals to tolerate $150 \mathrm{ppm} \mathrm{H}_{2} \mathrm{~S}$ [39]. It is strongly indicated that HIF-1 is required when animals response to $\mathrm{H}_{2} \mathrm{~S} . \mathrm{H}_{2} \mathrm{~S}$ treatment, as well as hypoxia, elevated the levels of HIF-1 protein and its activity [39]. However, $\mathrm{H}_{2} \mathrm{~S}$ and hypoxia caused different expression patterns of a HIF-1 target gene [39].

The effects of $\mathrm{H}_{2} \mathrm{~S}$ on HIF-1 in higher organisms have been investigated. In vascular smooth muscle cells, the interaction between $\mathrm{H}_{2} \mathrm{~S}$ and $\mathrm{HIF}-1$ was tested under $\mathrm{CoCl}_{2}$ induced hypoxia-mimetic conditions [40]. In a concentration of $300 \mu \mathrm{M}$, NaHS induced upregulation of HIF- $1 \alpha$ mRNA and proteins [40]. HIF-1 $\alpha$ transcription activity in the same context was also increased [40]. The authors suggested that $\mathrm{H}_{2} \mathrm{~S}$ upregulates HIF- $1 \alpha$ gene transcription. However, HIF$1 \alpha$ synthesis during hypoxia is largely regulated at the level of translation rather than transcription [21]. It is worthy of mentioning that although $\mathrm{CoCl}_{2}$ treatment could induce HIF- $1 \alpha$ accumulation to mimetic hypoxic stress, the model itself is not essential hypoxia and may cause other cellular changes [1].

Some later studies provided further understanding of the influence of $\mathrm{H}_{2} \mathrm{~S}$ on HIF-1 in mammalian cells. It is reported that $1 \mathrm{mM}$ NaHS $\left(\mathrm{H}_{2} \mathrm{~S}\right.$ donor) decreased hypoxia-induced HIF- $1 \alpha$ protein accumulation and HIF- 1 target gene expression in mammalian cell lines [22]. However, $\mathrm{H}_{2} \mathrm{~S}$ had no similar effect on HIF-1 in hypoxia-mimetic conditions [22]. In contrast, another study showed that $\mathrm{NaHS}$ at relatively low concentrations $(10-100 \mu \mathrm{M})$ treatment decreased HIF$1 \alpha$ protein levels in HEK293T, Hep3B, and EA.hy926 cells under both hypoxia $\left(1 \% \mathrm{O}_{2}\right)$ and hypoxia-mimetic conditions [23]. The controversial observations will be considered in subsequent sections.

2.3. Mechanisms of $\mathrm{H}_{2} \mathrm{~S}$ Effects on HIF-1 Accumulation. In the C. elegans study, $\mathrm{H}_{2} \mathrm{~S}$-induced HIF-1 accumulation was dependent on EGL-9, indicating that $\mathrm{H}_{2} \mathrm{~S}$ may prevent HIF1 degradation [39]. In the same study, $\mathrm{H}_{2} \mathrm{~S}$-evoked HIF1 increase was independent of VHL-1, which implies that
C. elegans may have a special HIF-1 degradation pathway. However, hypoxia-mediated HIF-1 accumulation in mammals is largely dependent on VHL-1. It has been shown that VHL-independent degradation pathways play important roles in controlling HIF-1 levels [21]. CYSL-1 is homologous to $\mathrm{CBS}$ which is a key enzyme for $\mathrm{H}_{2} \mathrm{~S}$ production in mammalian cells [41]. CYSL-1 identified from genetic screens negatively regulated EGL- 9 and thus enhanced HIF-1 stability [41]. It was proposed that $\mathrm{H}_{2} \mathrm{~S}$ promoted the interaction of EGL-9 and CYSL-1 to cause HIF-1 accumulation in C. elegans under hypoxia [41].

Kai and colleagues showed that $\mathrm{H}_{2} \mathrm{~S}$ did not affect HIF-1 levels in EB8 cells under hypoxia, compared with control cells [22]. The fact that EB8 cells have no mtDNA suggested that mitochondria was involved in $\mathrm{H}_{2} \mathrm{~S}$-inhibited HIF-1 activation [22]. The authors found that $1 \mathrm{mM} \mathrm{NaHS}$ inhibited mitochondrial oxygen consumption and thus increased the oxygen level in hypoxic cells. $\mathrm{H}_{2} \mathrm{~S}$ did not inhibit the stabilization of HIF- $1 \alpha$ protein under hypoxia-mimetic conditions [22]. The authors concluded that $\mathrm{H}_{2} \mathrm{~S}$ promoted HIF- $1 \alpha$ degradation under hypoxia, due to NaHS-induced mitochondrial oxygen consumption inhibition (Figure 1). However, they did not provide the direct evidence that the speed of HIF- $1 \alpha$ degradation was altered in the presence of $\mathrm{H}_{2} \mathrm{~S}$. On the other hand, it is worthy of mentioning that most of the key observations in their study were obtained with NaHS at $1 \mathrm{mM}$. This high concentration of $\mathrm{H}_{2} \mathrm{~S}$ is clearly not within the physiological range of endogenous $\mathrm{H}_{2} \mathrm{~S}$ and may have toxic effects on cells for long-time treatments $[1,42]$.

$\mathrm{NaHS}$ at $10-100 \mu \mathrm{M}$ has been used in different studies to reflect physiologically relevant concentrations of $\mathrm{H}_{2} \mathrm{~S}$ in vivo $[43,44]$. In a study using $\mathrm{NaHS}$ at $10-100 \mu \mathrm{M}$, NaHS significantly lowered HIF- $1 \alpha$ protein levels under both hypoxia $\left(1 \% \mathrm{O}_{2}\right)$ and hypoxia-mimetic conditions (DFX or $\mathrm{CoCl}_{2}$ ) [23]. Although inducing HIF-1 $\alpha$ accumulation, both DFX and $\mathrm{CoCl}_{2}$ have no effect on oxygen partial pressure in the culture medium [23]. It is suggested that oxygen partial pressure change or the alteration of mitochondrial respiration may not be involved in $\mathrm{H}_{2} \mathrm{~S}$-induced HIF-1 $\alpha$ downregulation under hypoxia. Both HIF-1 $\alpha$ degradation and HIF- $1 \alpha$ ubiquitination were not changed by NaHS treatment [23]. In contrast, cycloheximide (CHX), a translation inhibitor, blocked the effect of NaHS on HIF-1 $\alpha$ protein levels [23], suggesting that $\mathrm{H}_{2} \mathrm{~S}$ mediates HIF- $1 \alpha$ translation suppression. The authors further demonstrated that the key mechanism for $\mathrm{H}_{2} \mathrm{~S}$-induced HIF-1 $\alpha$ downregulation was $\mathrm{H}_{2} \mathrm{~S}$-evoked repression of HIF- $1 \alpha$ protein translation, rather than an effect on the ubiquitin proteasomal degradation pathway (Figure 1). Eukaryotic translation initiation factor $2 \alpha$ (eIF $2 \alpha$ ) is a critical regulatory molecule for eukaryotic initiation of translation [21]. eIF $2 \alpha$ is responsible for the transformation of GDP to GTP, an essential step for translation start. Phosphorylation of eIF2 $\alpha$ at Ser51 prevents the reformation of the eIF-2 ternary complex and thus inhibits protein translation [21]. Certain antitumour compounds which essentially decrease HIF- $1 \alpha$ translation contribute to eIF $2 \alpha$ phosphorylation [34, 35]. In eIF $2 \alpha$ knockdown cells exposed to hypoxia, $\mathrm{H}_{2} \mathrm{~S}$ induced reduction of HIF- $1 \alpha$ was partially reversed [23]. Therefore, HIF- $1 \alpha$ translational suppression is associated with 
$\mathrm{H}_{2} \mathrm{~S}$-induced eIF2 $\alpha$ phosphorylation in hypoxic contexts (Figure 1).

In summary of this section, it is likely that two key factors, the extent of hypoxia together with the concentration of $\mathrm{H}_{2} \mathrm{~S}$ in the same condition, determine the final result of the action of $\mathrm{H}_{2} \mathrm{~S}$ on HIF-1. $\mathrm{H}_{2} \mathrm{~S}$-induced upregulation of HIF-1 was observed in a C. elegans model. C. elegans naturally lives where $\mathrm{O}_{2}$ level is lower than that in the air $[6,7]$. The animals have no circulatory system. $\mathrm{O}_{2}$ delivery in this species is dependent on diffusion. C. elegans are able to survive from $\mathrm{O}_{2}$ depletion, due to an anoxia-induced suspended animation state [6,7]. In contrast, models in which $\mathrm{H}_{2} \mathrm{~S}$-triggered downregulation of HIF-1 come from high organisms which are highly oxygen-demanded. The differences in both species and oxygen demand may explain the opposite regulational patterns in the action of $\mathrm{H}_{2} \mathrm{~S}$ on HIF-1. On the other hand, the effect of $\mathrm{H}_{2} \mathrm{~S}$ on HIF1 regulation may be dose-dependent. Differences in NaHS concentrations may be correlated with various observations in abovementioned studies. Thus, further studies on the role of endogenous $\mathrm{H}_{2} \mathrm{~S}$ may provide further understanding of the interaction between $\mathrm{H}_{2} \mathrm{~S}$ and HIF-1.

Emerging evidence indicates that VHL-independent HIF-1 $\alpha$ degradation has an important role in controlling HIF-1 $\alpha$ levels. Although this kind of pathways seems to be less dependent on oxygen levels in cells, that is, receptor of activated protein kinase C- (RACK1) mediated HIF-1 $\alpha$ degradation [21], and further research is still required to solve whether these pathways are involved in the effect of $\mathrm{H}_{2} \mathrm{~S}$ on HIF-1 in hypoxic contexts. On the other hand, translational regulation of HIF- $1 \alpha$ under hypoxia is largely elusive. Therefore, whether $\mathrm{H}_{2} \mathrm{~S}$ targets other factors which potentially regulate HIF- $1 \alpha$ translation is another challenge. Moreover, it is not yet clear how $\mathrm{H}_{2} \mathrm{~S}$-mediated HIF- $1 \alpha$ regulation contributes to the protective role of $\mathrm{H}_{2} \mathrm{~S}$ under hypoxia.

\section{3. $\mathrm{H}_{2} \mathrm{~S}$ and Hypoxic Sensing in the Carotid Body}

3.1. $\mathrm{O}_{2}$ Sensing in the Carotid Body. With the remarkable sensitivity and the fast speed to hypoxic response, the carotid body plays a unique role in $\mathrm{O}_{2}$ sensing [19]. Carotid bodies are small sensory organs located at the bifurcation of the common carotid artery $[14,19]$. Changes in $\mathrm{O}_{2}$ levels of arterial blood rapidly active the carotid bodies, which in turn transduce sensory information to brainstem neurons [14]. The final response in the central nervous system regulates vital functions including breathing, heart rate, and blood pressure to increase ventilation and systemic delivery of oxygen [15]. Carotid bodies are primarily composed of two cell types: glomus cells (also called type I cells) and sustentacular cells (also called type II cells) [15]. Accumulated evidence suggests that type I cells are the primary site of hypoxic sensing in carotid bodies. $\mathrm{NO}$ and $\mathrm{CO}$ inhibited carotid body activity [15]. Neuronal nitric oxide synthase- (nNOS) generated NO has been proposed as an important mediator of efferent inhibition of the carotid body [25, 45]. Heme oxygenase-2 (HO-2), a key enzyme for CO production, is expressed in glomus cells of many mammalian carotid bodies $[24,46]$. Exogenous application of $\mathrm{CO}$ at low concentrations and $\mathrm{HO}$ inhibitors inhibited and stimulated the carotid body activity, respectively $[16,24]$.

3.2. Effects of $\mathrm{CSE} / \mathrm{H}_{2} \mathrm{~S}$ on Carotid Body Activity. Emerging evidence demonstrated that $\mathrm{H}_{2} \mathrm{~S}$ is involved in sensing and response to hypoxia in many tissues that possess the ability to sense hypoxia. $\mathrm{H}_{2} \mathrm{~S}$ stimulated catecholamine secretion from chromaffin cells in trout [30]. $\mathrm{H}_{2} \mathrm{~S}$ regulated the $\mathrm{O}_{2}$ sensing signal in trout chemoreceptors [47]. It was proposed that the balance between endogenous $\mathrm{H}_{2} \mathrm{~S}$ production and its oxidation by available $\mathrm{O}_{2}$ contributed to $\mathrm{H}_{2} \mathrm{~S}$-mediated $\mathrm{O}_{2}$ sensing [47]. Recent studies showed that $\mathrm{H}_{2} \mathrm{~S}$, like $\mathrm{NO}$ and $\mathrm{CO}$, is another gas regulator for hypoxic sensing in carotid bodies. Both CSE [26] and CBS proteins [27] are expressed in glomus cells. Rat carotid body expresses mRNAs for both CBS and CSE [48]. Hypoxia increased $\mathrm{H}_{2} \mathrm{~S}$ generation in both mouse and rat carotid bodies [26]. Hypoxia-induced $\mathrm{H}_{2} \mathrm{~S}$ production and secretion of catecholamine were significantly decreased in CSE knockout mice or in wide-type mice treated with CSE inhibitors DL-propargylglycine (PPG) [26]. CSE knockout mice exhibited severely impaired function of carotid body sensing to hypoxia. The similar observation was shown in rats treated with PPG [26]. Exogenous application of $\mathrm{H}_{2} \mathrm{~S}$ donor, $\mathrm{NaHS}$, increased the sensory excitation of the carotid bodies from mice and rats [26, 27]. The patterns of NaHS action on carotid bodies are similar to that of hypoxia. $\mathrm{H}_{2} \mathrm{~S}$ produced by CSE may function as an excitatory mediator for the sensory excitation by hypoxia [26] (Figure 2).

\subsection{Potential Effects of $\mathrm{CBS} / \mathrm{H}_{2} \mathrm{~S}$ on $\mathrm{O}_{2}$ Sensing in Carotid} Body. It is worthy of mentioning that, in CSE knockout mice, the basal levels of $\mathrm{H}_{2} \mathrm{~S}$ in the carotid bodies were half reduced compared to those of control wild-type animals [26]. It is likely that CBS may also be responsible for $\mathrm{H}_{2} \mathrm{~S}$ production in the carotid bodies. Aminooxyacetic acid (AOA) and hydroxylamine (HA), two inhibitors of CBS, suppressed carotid body and ventilatory responses to hypoxia [27]. This study suggested that CBS-catalyzed $\mathrm{H}_{2} \mathrm{~S}$ also plays a role in excitatory carotid bodies sensing under hypoxia (Figure 2). Compared to CSE inhibitor PPG, AOA and $\mathrm{HA}$ are nonspecific inhibitors [1]. HA inhibits many heme-containing enzymes $[49,50]$, while AOA generally targets aminotransferase $[51,52]$. Given the pharmacologic nonspecific inhibition, further studies need to elucidate the effects of endogenous $\mathrm{CBS}$ on $\mathrm{O}_{2}$ sensing in carotid bodies. In addition, the relative importance of $\mathrm{H}_{2} \mathrm{~S} / \mathrm{CSE}$ and $\mathrm{H}_{2} \mathrm{~S} / \mathrm{CBS}$ on carotid bodies hypoxic sensing needs to be established.

The role of $\mathrm{H}_{2} \mathrm{~S} / \mathrm{CBS}$ in $\mathrm{O}_{2}$ sensing in tissues, other than carotid bodies, has been revealed in recent studies. CBS is a nuclear encoding heme protein [8]. The levels of CBS proteins in liver mitochondria are regulated in a Lon protease-mediated $\mathrm{O}_{2}$-dependent pathway [8]. Under normoxic conditions, a low level of CBS proteins was shown in mitochondria [8]. Hypoxia inhibited Lon protease activity and thus increased the accumulation of CBS in mitochondria 


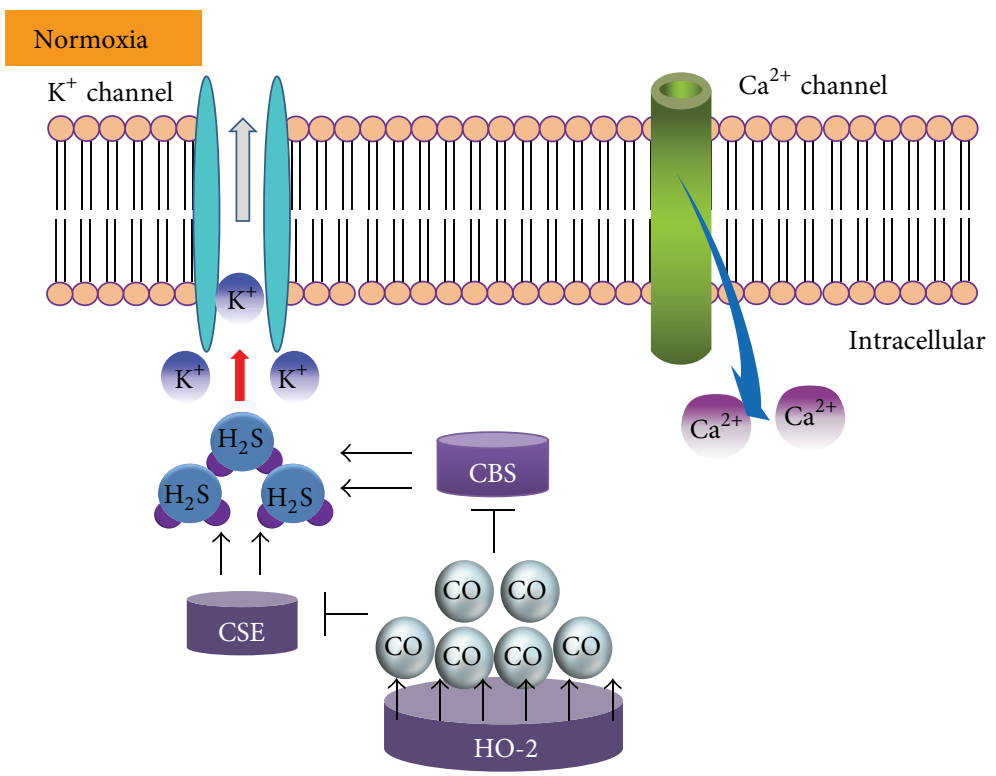

(a)

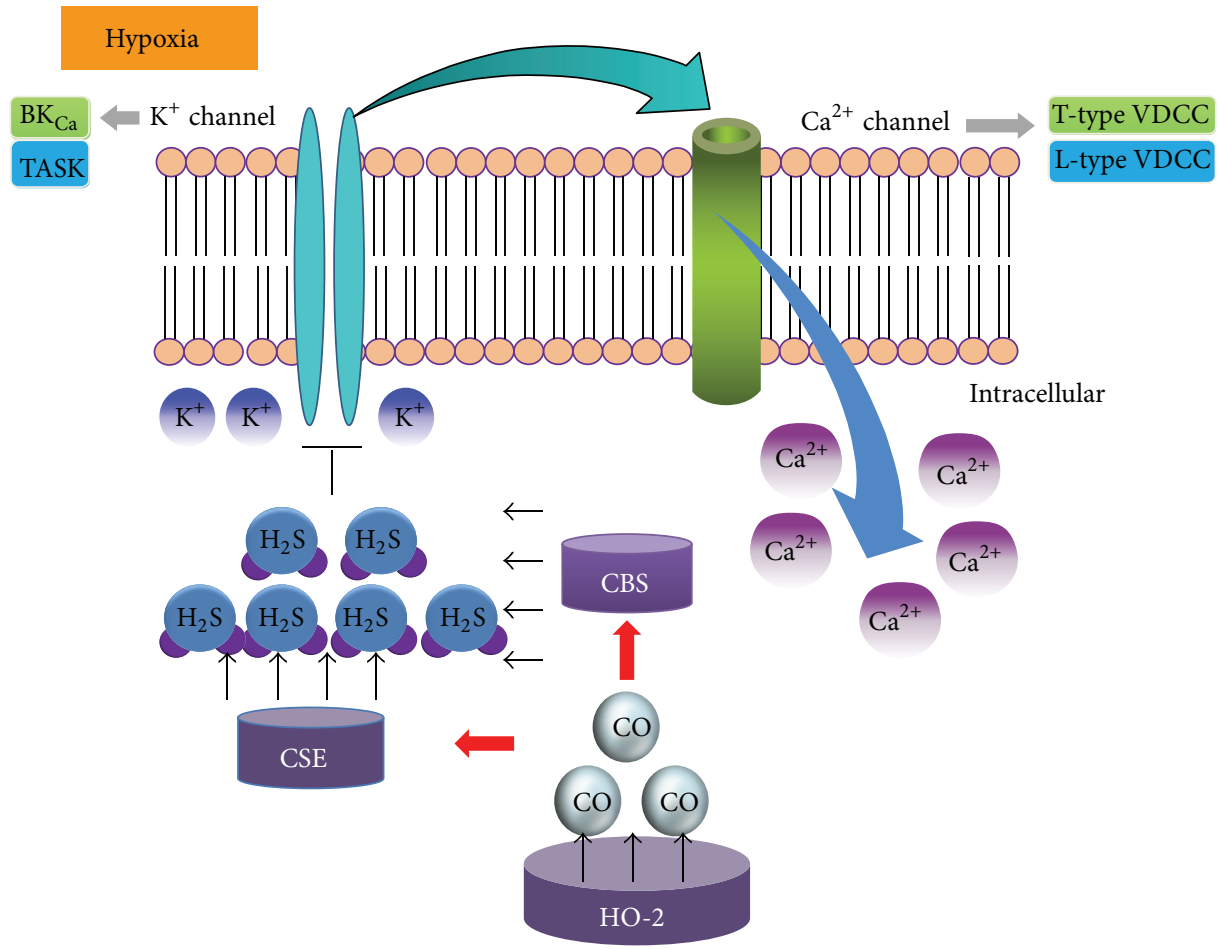

(b)

FIgURE 2: Potential interaction of heme oxygenase-2- (HO-2-) generated CO with cystathionine $\gamma$-lyase (CSE) and cystathionine $\beta$-synthase (CBS) in glomus cells of the carotid body. (a) Under normoxia, HO-2-generated CO is relatively high, resulting in inhibition of both CSE and CBS activity. $\mathrm{H}_{2} \mathrm{~S}$ production is relatively low, contributing to low sensory activity in glomus cells. (b) Under hypoxia, CO generation from HO-2 is reduced, resulting in removal of CO inhibition on CSE and CBS activity. $\mathrm{H}_{2} \mathrm{~S}$ levels are increased due to enhanced CSE and CBS activities. Increased $\mathrm{H}_{2} \mathrm{~S}$ may activate $\mathrm{Ca}^{2+}$ channels due to membrane depolarization via the inhibition of $\mathrm{K}^{+}$channels, which in turn excites sensory responses in glomus cells. 
[8]. Reoxygenation recovered Lon protease activity and thus accelerated the degradation of CBS proteins [8]. This study indicates that CBS accumulated in mitochondria is oxygensensitive. CBS serves as a CO-sensitive modulator of $\mathrm{H}_{2} \mathrm{~S}$ in liver [53]. Studies using recombinant CBS indicated that $\mathrm{CO}$ bound to the prosthetic heme in CBS and thus specifically inhibited CBS activity [53]. In livers of heterozygous CBS knockout mice, overproducing $\mathrm{CO}$ had no effect on $\mathrm{H}_{2} \mathrm{~S}$ generation. Another further study showed that CBS-catalyzed $\mathrm{H}_{2} \mathrm{~S}$ functioned as a vasodilator in the cerebral circulation [54]. CO produced by $\mathrm{HO}-2$ was $\mathrm{O}_{2}$-dependent in the brain. Endogenous CO negatively regulated CBS activity under normoxia, while, under hypoxia, CBS activity was increased due to the decrease of CO production [54]. However, it is not clear whether the interaction between $\mathrm{CO}$ and $\mathrm{CBS}$ affects the sensory action of carotid body.

3.4. Mechanisms of Regulating Carotid Body Activity by $\mathrm{H}_{2} \mathrm{~S}$. Recent studies showed that hypoxia induces the opening of voltage-dependent $\mathrm{Ca}^{2+}$ channels (VDCC) through inhibition of $\mathrm{K}^{+}$channels in carotid bodies $[14,15]$. VDCC activation increases intracellular $\mathrm{Ca}^{2+}$ concentration $\left(\left[\mathrm{Ca}^{2+}\right]_{\mathrm{i}}\right)$ and thus enhances the release of neurotransmitters under hypoxia $[15,19]$ (Figure 2). NaHS inhibited big-conductance $\mathrm{Ca}^{2+}$-sensitive $\mathrm{K}^{+}\left(\mathrm{BK}_{\mathrm{Ca}}\right)$ channels $[27,48]$, background $\mathrm{K}^{+}$ current (TASK) [55], and elevated $\left[\mathrm{Ca}^{2+}\right]_{\mathrm{i}}$ in glomus cells [55]. NaHS-induced elevation of $\left[\mathrm{Ca}^{2+}\right]_{i}$ was abolished in the absence of extracellular $\mathrm{Ca}^{2+}[55,56]$ or in case that the depolarization was prevented by voltage clamping at the resting membrane potential [55]. In cultured rat glomus cells, NaHS-induced elevation of $\left[\mathrm{Ca}^{2+}\right]_{\mathrm{i}}$ was blocked by nifedipine, a L-type VDCC blocker [56]. Similar finding was observed in both astrocytes [57] and rat neurons [58]. These findings support the view that L-type VDCC may be involved in $\mathrm{H}_{2} \mathrm{~S}$-induced elevation of $\left[\mathrm{Ca}^{2+}\right]_{\mathrm{i}}$ in carotid bodies [56] (Figure 2). A series of studies demonstrated that $\mathrm{H}_{2} \mathrm{~S}$ was also involved in the activation of T-type VDCC [59-61]. More recently, it is suggested that $\mathrm{Ca}_{\mathrm{V}} 3.2 \mathrm{~T}$-type VDCC contributed to $\mathrm{H}_{2} \mathrm{~S}$ mediated carotid body response to hypoxia [62] $\mathrm{Ca}_{\mathrm{V}} 3.2$ was the major T-Type VDCC isoform expressed in the carotid body [62] (Figure 2). In brief, all abovementioned observations indicate that $\mathrm{H}_{2} \mathrm{~S}$ may function as a physiological excitatory mediator of the carotid body sensory response to hypoxia (Figure 2). Moreover ion channels are closely correlated with this regulation (Figure 2).

In addition, exogenous application of $\mathrm{H}_{2} \mathrm{~S}$ inhibited mitochondrial function in rat glomus cells [55]. The author proposed that the inhibitory effect of $\mathrm{H}_{2} \mathrm{~S}$ on TASK was due to inhibition of oxidative phosphorylation. Given that mitochondrial reactive oxygen species is speculated to mediate carotid body action [63, 64], whether mitochondria is directly involved in $\mathrm{H}_{2} \mathrm{~S}$-mediated excitatory sensing in carotid bodies needs to be demonstrated. In addition, it is reported that neurotransmitters were involved in $\mathrm{H}_{2} \mathrm{~S}$ induced sensory excitation of carotid bodies. Acetylcholine (ACh) and adenosine triphosphate (ATP) are two excitatory neurotransmitters in the carotid bodies of both cats and rats $[27,65,66]$. Inhibition of purinergic receptors using pyridoxal phosphate-6-azophenyl-2 ${ }^{\prime}, 4^{\prime}$-disulfonic acid, or application of hexamethonium, a blocker of nicotinic cholinergic receptors, prevented NaHS-evoked sensory excitation of the mouse carotid body [27]. This study indicates that the release of ATP/ACh from glomus cells is correlated with $\mathrm{H}_{2} \mathrm{~S}$-induced sensory excitation. However, $\mathrm{Na}_{2} \mathrm{~S}$ (another $\mathrm{H}_{2} \mathrm{~S}$ donors) significantly reduced the release of both ACh and ATP in the cat carotid body [65]. The effect of $\mathrm{H}_{2} \mathrm{~S}$ on neurotransmitters release needs to be further established. Whether neurotransmitters release is associated with $\mathrm{H}_{2} \mathrm{~S}$ regulated carotid body activity is not clear.

3.5. Hypoxia-Induced $\mathrm{H}_{2} \mathrm{~S}$ Increase: Evidence for Interaction of CSE with HO-2. In CSE knockout mice and rats treated with PPG, hypoxia failed to increase $\mathrm{H}_{2} \mathrm{~S}$ generation in both mouse and rat carotid bodies [26]. These observations suggested that hypoxia-induced $\mathrm{H}_{2} \mathrm{~S}$ production may be due to increased CSE activity. Hemeoxygenase-2 (HO-2) converts heme to CO [67]. HO-2 is constitutively expressed in type I cells of mammals [16]. It has been demonstrated that $\mathrm{CO}$ is an inhibitory mediator for carotid bodies hypoxia sensing [16] (Figure 2). Under normoxia, pharmacological inhibition of HO-2 greatly increased $\mathrm{H}_{2} \mathrm{~S}$ generation [26]. In contrast, a $\mathrm{CO}$ donor inhibited the hypoxia-evoked $\mathrm{H}_{2} \mathrm{~S}$ production in the carotid body [26]. These couple of findings suggested that $\mathrm{CO}$ may be a negative regulator for $\mathrm{H}_{2} \mathrm{~S}$ production in the carotid body (Figure 2). In CSE knockout mice, the HO-2 inhibitor had no effect on $\mathrm{H}_{2} \mathrm{~S}$ generation. Under hypoxia, reduced $\mathrm{CO}$ generation may improve $\mathrm{H}_{2} \mathrm{~S}$ generation and the sensory action of the carotid body [26]. Taken together, it was proposed that $\mathrm{H}_{2} \mathrm{~S}$ generation is negatively controlled by $\mathrm{CO}$ inhibited CSE activity [26] (Figure 2). Given that CSE does not contain a heme group, this enzyme is unlikely to be bound by CO $[1,14]$. To date, the mechanisms by which CO inhibits CSE activity are still unknown.

3.6. $\mathrm{H}_{2} \mathrm{~S}$-Mediated Sensory Activity of Carotid Bodies in Diseases. More recently, inherent variations in CO-mediated $\mathrm{H}_{2} \mathrm{~S}$ have been shown to contribute to reflex variation of carotid body $\mathrm{O}_{2}$ sensing in three genetically distinct rat strains, including Sprague-Dawley (SD) rats, Brown-Norway (BN) rats, and spontaneous hypertensive (SH) rats [28]. In comparison with $\mathrm{SD}$ rats, $\mathrm{BN}$ rats display a profoundly reduced ventilatory response to hypoxia and also develop pulmonary edema when challenged with hypoxia $[28,68]$. SH rats, compared with SD rats, exhibit an exaggerated response to hypoxia [69] and this alteration is vital for the development of essential hypertension [70]. Variability in kinetic properties of HO-2 was shown in liver microsomes from SD, BN, and $\mathrm{SH}$ rats, consistent with changes in $\mathrm{CO}$ levels from these three rat strains [28]. The authors proposed that variability of HO-2 activity of the liver was similar to that of the carotid bodies, based on the observation that hypoxic responses of the liver microsomes paralleled those of carotid bodies in the respective strain [28]. Impaired hypoxic sensitivity in $\mathrm{BN}$ rats was associated with augmented basal levels of $\mathrm{CO}$ and reduced $\mathrm{H}_{2} \mathrm{~S}$ [28]. In contrast, the exaggerated hypoxic response in $\mathrm{SH}$ rats was correlated with 
lower $\mathrm{CO}$ and higher basal $\mathrm{H}_{2} \mathrm{~S}$ [28]. Different substrate affinities for $\mathrm{HO}-2$ resulted in various basal levels of $\mathrm{CO}$ and $\mathrm{H}_{2} \mathrm{~S}$ generation [28]. Taken together, this series of findings further demonstrates that $\mathrm{CO}-\mathrm{H}_{2} \mathrm{~S}$-mediated $\mathrm{O}_{2}$ sensing is a fundamental mechanism in the carotid body chemosensory reflex [28].

\section{Summary and Perspective}

An abundant and continuous supply of $\mathrm{O}_{2}$ is essential for survival of all mammalian cells. Reduced $\mathrm{O}_{2}$ availability or hypoxia evokes many important physiological responses and changes, for the sake of increasing oxygen delivery. The activation of carotid bodies is a sensitive and prompt response to hypoxia, rapidly enhancing general $\mathrm{O}_{2}$ supply. The family of HIFs, master regulators of cellular $\mathrm{O}_{2}$, induces an elegant series of delayed changes through activating target genes expression under hypoxia.

Emerging evidence shows that $\mathrm{H}_{2} \mathrm{~S}$ plays a crucial role in $\mathrm{O}_{2}$ sensing, through regulating carotid body activity and HIF-1 action. The regulation of HIF-1 accumulation via exogenous $\mathrm{H}_{2} \mathrm{~S}$ has been shown, but the mechanisms for this effect are largely elusive and controversial. The patterns for $\mathrm{H}_{2} \mathrm{~S}$-regulated HIF-1 may be dose-dependent. Further studies need to identify the role of endogenous $\mathrm{H}_{2} \mathrm{~S}$ on HIF-1 action. Compared with many studies on the role of $\mathrm{H}_{2} \mathrm{~S}$ on HIF$1 \alpha$, few have been done to elucidate the interaction between $\mathrm{H}_{2} \mathrm{~S}$ and HIF- $2 \alpha$. Glomus cells had higher expression of HIF$2 \alpha$ than that of HIF- $1 \alpha$ [71]. Heterozygous HIF- $1 \alpha$ geneknockout mice had no carotid bodies responses to hypoxia [72]. Carotid bodies from mice with heterozygous knockout of HIF- $2 \alpha$ gene exhibited exaggerated responses to hypoxia [73]. It was proposed that a balance between HIF-1 $\alpha$ and HIF- $2 \alpha$ contributed to changes of redox homeostasis in the carotid body [15]. Based on this hypothesis, would $\mathrm{H}_{2} \mathrm{~S}$ affect HIF- $1 \alpha$ and/or HIF- $2 \alpha$ in the carotid body? Endogenously generated $\mathrm{H}_{2} \mathrm{~S}$ has been shown as a stimulator of carotid body activity under hypoxia. Although $\mathrm{CO}$ has been shown to negatively regulate CSE-catalyzed $\mathrm{H}_{2} \mathrm{~S}$ production, the accurate molecular mechanisms by which CO affects CSE activity are still unknown. Moreover, the effect of $\mathrm{CBS} / \mathrm{H}_{2} \mathrm{~S}$ on carotid body action is elusive.

One of the most recently identified mechanisms for $\mathrm{H}_{2} \mathrm{~S}$ effect is $S$-sulfhydration [74-76]. The potential targets of $\mathrm{S}$-sulfhydration in $\mathrm{H}_{2} \mathrm{~S}$-mediated $\mathrm{O}_{2}$ sensing remain to be determined. In addition, a novel study showed that $\mathrm{H}_{2} \mathrm{~S}$ activated protein kinase $\mathrm{G}$ (PKG) I $\alpha$ oxidation by inducing disulfide formation [77]. The key mediator in that event is polysulfides. $\mathrm{H}_{2} \mathrm{~S}$ rapidly converts to polysulfides when $\mathrm{H}_{2} \mathrm{~S}$ contacts $\mathrm{O}_{2}$ or hydrogen peroxide $[1,77]$. It is not yet clear whether polysulfides are involved in $\mathrm{H}_{2} \mathrm{~S}$-mediated carotid body response to hypoxia or $\mathrm{H}_{2} \mathrm{~S}$-regulated HIF functions.

\section{Conflict of Interests}

The authors declare that there is no conflict of interests regarding the publication of this paper.

\section{Acknowledgment}

This work was supported by National Natural Science Foundation of China (81400210), Science Foundation for Returned Scholars of Heilongjiang (LC201433), Heilongjiang Postdoctoral Fund (LBH-Z13141), and Scientific Research Project of Health Department of Heilongjiang (2011-214).

\section{References}

[1] R. Wang, "Physiological implications of hydrogen sulfide: a whiff exploration that blossomed," Physiological Reviews, vol. 92, no. 2, pp. 791-896, 2012.

[2] R. Wang, "Hydrogen sulfide: the third gasotransmitter in biology and medicine," Antioxidants and Redox Signaling, vol. 12, no. 9, pp. 1061-1064, 2010.

[3] H. Kimura, "Hydrogen sulfide: from brain to gut," Antioxidants and Redox Signaling, vol. 12, no. 9, pp. 1111-1123, 2010.

[4] K. R. Olson, "Hydrogen sulfide as an oxygen sensor," Clinical Chemistry and Laboratory Medicine, vol. 51, no. 3, pp. 623-632, 2014.

[5] H. Kimura, "Hydrogen sulfide and polysulfides as biological mediators," Molecules, vol. 19, no. 10, pp. 16146-16157, 2014.

[6] N. N. Iranon and D. L. Miller, "Interactions between oxygen homeostasis, food availability, and hydrogen sulfide signaling," Frontiers in Genetics, vol. 3, article 257, 2012.

[7] C. Shen and J. A. Powell-Coffman, "Genetic analysis of hypoxia signaling and response in C. elegans," Annals of the New York Academy of Sciences, vol. 995, pp. 191-199, 2003.

[8] H. Teng, B. Wu, K. Zhao, G. Yang, L. Wu, and R. Wang, "Oxygen-sensitive mitochondrial accumulation of cystathionine $\beta$-synthase mediated by Lon protease," Proceedings of the National Academy of Sciences of the United States of America, vol. 110, no. 31, pp. 12679-12684, 2013.

[9] Y. Kimura and H. Kimura, "Hydrogen sulfide protects neurons from oxidative stress," The FASEB Journal, vol. 18, no. 10, pp. 1165-1167, 2004.

[10] J. L. Wallace, "Physiological and pathophysiological roles of hydrogen sulfide in the gastrointestinal tract," Antioxidants and Redox Signaling, vol. 12, no. 9, pp. 1125-1133, 2010.

[11] G. Yang, L. Wu, S. Bryan, N. Khaper, S. Mani, and R. Wang, "Cystathionine gamma-lyase deficiency and overproliferation of smooth muscle cells," Cardiovascular Research, vol. 86, no. 3, pp. 487-495, 2010.

[12] G. Yang, K. Cao, L. Wu, and R. Wang, "Cystathionine gammalyase overexpression inhibits cell proliferation via a $\mathrm{H}_{2} \mathrm{~S}$ dependent modulation of ERK1/2 phosphorylation and p21 Cip/WAK-1," The Journal of Biological Chemistry, vol. 279, no. 47, pp. 49199-49205, 2004.

[13] G. Yang, L. Wu, B. Jiang et al., " $\mathrm{H}_{2} \mathrm{~S}$ as a physiologic vasorelaxant: hypertension in mice with deletion of cystathionine $\gamma$ lyase," Science, vol. 322, no. 5901, pp. 587-590, 2008.

[14] G. L. Semenza and N. R. Prabhakar, "Gas biology: small molecular medicine," Journal of Molecular Medicine, vol. 90, no. 3, pp. 213-215, 2012.

[15] N. R. Prabhakar and G. L. Semenza, "Gaseous messengers in oxygen sensing," Journal of Molecular Medicine, vol. 90, no. 3, pp. 265-272, 2012.

[16] N. R. Prabhakar, J. L. Dinerman, F. H. Agani, and S. H. Snyder, "Carbon monoxide: a role in carotid body chemoreception," 
Proceedings of the National Academy of Sciences of the United States of America, vol. 92, no. 6, pp. 1994-1997, 1995.

[17] K. R. Olson and N. L. Whitfield, "Hydrogen sulfide and oxygen sensing in the cardiovascular system," Antioxidants and Redox Signaling, vol. 12, no. 10, pp. 1219-1234, 2010.

[18] G. L. Semenza, "Hypoxia. Cross talk between oxygen sensing and the cell cycle machinery," The American Journal of Physiology-Cell Physiology, vol.301, no. 3, pp. C550-C552, 2011.

[19] N. R. Prabhakar, "Sensing hypoxia: Physiology, genetics and epigenetics," Journal of Physiology, vol. 591, no. 9, pp. 2245-2257, 2013.

[20] S. Rocha, "Gene regulation under low oxygen: holding your breath for transcription," Trends in Biochemical Sciences, vol. 32, no. 8, pp. 389-397, 2007.

[21] M. Y. Koh, T. R. Spivak-Kroizman, and G. Powis, "HIF-1 regulation: not so easy come, easy go," Trends in Biochemical Sciences, vol. 33, no. 11, pp. 526-534, 2008.

[22] S. Kai, T. Tanaka, H. Daijo et al., "Hydrogen sulfide inhibits hypoxia-but not anoxia-induced hypoxia-inducible factor 1 activation in a von Hippel-Lindau-and mitochondriadependent manner," Antioxidants and Redox Signaling, vol. 16, no. 3, pp. 203-216, 2012.

[23] B. Wu, H. Teng, G. Yang, L. Wu, and R. Wang, "Hydrogen sulfide inhibits the translational expression of hypoxia-inducible factor-1alpha," British Journal of Pharmacology, vol. 167, no. 7, pp. 1492-1505, 2012.

[24] P. Ortega-Sáenz, A. Pascual, R. Gómez-Díaz, and J. LópezBarneo, "Acute oxygen sensing in heme oxygenase-2 null mice," Journal of General Physiology, vol. 128, no. 4, pp. 405-411, 2006.

[25] N. R. Prabhakar, G. K. Kumar, C. H. Chang, F. H. Agani, and M. A. Haxhiu, "Nitric oxide in the sensory function of the carotid body," Brain Research, vol. 625, no. 1, pp. 16-22, 1993.

[26] Y. J. Peng, J. Nanduri, G. Raghuraman et al., " $\mathrm{H}_{2} \mathrm{~S}$ mediates $\mathrm{O}_{2}$ sensing in the carotid body," Proceedings of the National Academy of Sciences United States of America, vol. 107, no. 23, pp. 10719-10724, 2010.

[27] Q. Li, B. Sun, X. Wang et al., "A crucial role for hydrogen sulfide in oxygen sensing via modulating large conductance calcium-activated potassium channels," Antioxidants and Redox Signaling, vol. 12, no. 10, pp. 1179-1189, 2010.

[28] Y. J. Peng, V. V. Makarenko, J. Nanduri et al., "Inherent variations in $\mathrm{Co}-\mathrm{H}_{2} \mathrm{~S}$-mediated carotid body $\mathrm{O}_{2}$ sensing mediate hypertension and pulmonary edema," Proceedings of the National Academy of Sciences of the United States of America, vol. 111, no. 3, pp. 1174-1179, 2014.

[29] G. L. Wang and G. L. Semenza, "Desferrioxamine induces erythropoietin gene expression and hypoxia-inducible factor 1 DNA-binding activity: implications for models of hypoxia signal transduction," Blood, vol. 82, no. 12, pp. 3610-3615, 1993.

[30] S. F. Perry, B. McNeill, E. Elia, A. Nagpal, and B. Vulesevic, "Hydrogen sulfide stimulates catecholamine secretion in rainbow trout (Oncorhynchus mykiss)," The American Journal of Physiology-Regulatory Integrative and Comparative Physiology, vol. 296, no. 1, pp. R133-R140, 2009.

[31] G. L. Wang, B. H. Jiang, E. A. Rue, and G. L. Semenza, "Hypoxiainducible factor 1 is a basic-helix-loop-helix-PAS heterodimer regulated by cellular $\mathrm{O}_{2}$ tension," Proceedings of the National Academy of Sciences of the United States of America, vol. 92, no. 12, pp. 5510-5514, 1995.

[32] G. L. Semenza, "Regulation of physiological responses to continuous and intermittent hypoxia by hypoxia-inducible factor 1," Experimental Physiology, vol. 91, no. 5, pp. 803-806, 2006.
[33] C. Peers, C. N. Wyatt, and A. M. Evans, "Mechanisms for acute oxygen sensing in the carotid body," Respiratory Physiology and Neurobiology, vol. 174, no. 3, pp. 292-298, 2010.

[34] H. J. Jung, J. W. Park, J. S. Lee et al., “Silibinin inhibits expression of HIF-lalpha through suppression of protein translation in prostate cancer cells," Biochemical and Biophysical Research Communications, vol. 390, no. 1, pp. 71-76, 2009.

[35] J. Zhang, J. Cao, Q. Weng et al., "Suppression of hypoxiainducible factor lalpha (HIF-lalpha) by tirapazamine is dependent on eiF2alpha phosphorylation rather than the mTORC1/4E-BP1 pathway," PLoS ONE, vol. 5, no. 11, Article ID e13910, 2010.

[36] T. Hagen, C. T. Taylor, F. Lam, and S. Moncada, "Redistribution of intracellular oxygen in hypoxia by nitric oxide: effect on HIFlalpha," Science, vol. 302, no. 5652, pp. 1975-1978, 2003.

[37] E. Metzen, J. Zhou, W. Jelkmann, J. Fandrey, and B. Brüne, "Nitric oxide impairs normoxic degradation of HIF-1alpha by inhibition of prolyl hydroxylases," Molecular Biology of the Cell, vol. 14, no. 8, pp. 3470-3481, 2003.

[38] Y. K. Choi, C.-K. Kim, H. Lee et al., "Carbon monoxide promotes VEGF expression by increasing HIF-lalpha protein level via two distinct mechanisms, translational activation and stabilization of HIF-1alpha protein," The Journal of Biological Chemistry, vol. 285, no. 42, pp. 32116-32125, 2010.

[39] M. W. Budde and M. B. Roth, "Hydrogen sulfide increases hypoxia-inducible factor-1 activity independently of von Hippel-Lindau tumor suppressor-1 in C. elegans," Molecular Biology of the Cell, vol. 21, no. 1, pp. 212-217, 2010.

[40] X. H. Liu, L. L. Pan, Y. Zhuo, Q. H. Gong, P. Rose, and Y. Z. $\mathrm{Zhu}$, "Hypoxia-inducible factor-lalpha is involved in the proangiogenic effect of hydrogen sulfide under hypoxic stress," Biological and Pharmaceutical Bulletin, vol. 33, no. 9, pp. 15501554, 2010.

[41] D. K. Ma, R. Vozdek, N. Bhatla, and H. R. Horvitz, "CYSL-1 interacts with the $\mathrm{O}_{2}$-sensing hydroxylase EGL-9 to promote $\mathrm{H}_{2} \mathrm{~S}$-modulated hypoxia-induced behavioral plasticity in $C$. elegans," Neuron, vol. 73, no. 5, pp. 925-940, 2012.

[42] P. K. Moore, M. Bhatia, and S. Moochhala, "Hydrogen sulfide: from the smell of the past to the mediator of the future?" Trends in Pharmacological Sciences, vol. 24, no. 12, pp. 609-611, 2003.

[43] G. Yang, H. Li, G. Tang et al., "Increased neointimal formation in cystathionine gamma-lyase deficient mice: role of hydrogen sulfide in alpha5betal-integrin and matrix metalloproteinase2 expression in smooth muscle cells," Journal of Molecular and Cellular Cardiology, vol. 52, no. 3, pp. 677-688, 2012.

[44] G. Yang, W. Yang, L. Wu, and R. Wang, " $\mathrm{H}_{2} \mathrm{~S}$, endoplasmic reticulum stress, and apoptosis of insulin-secreting beta cells," The Journal of Biological Chemistry, vol. 282, no. 22, pp. 1656716576, 2007.

[45] V. A. Campanucci and C. A. Nurse, "Autonomic innervation of the carotid body: Role in efferent inhibition," Respiratory Physiology and Neurobiology, vol. 157, no. 1, pp. 83-92, 2007.

[46] S. Mkrtchian, J. Kåhlin, A. Ebberyd et al., "The human carotid body transcriptome with focus on oxygen sensing and inflammation-a comparative analysis," Journal of Physiology, vol. 590, no. 16, pp. 3807-3819, 2012.

[47] K. R. Olson, R. A. Dombkowski, M. J. Russell et al., "Hydrogen sulfide as an oxygen sensor/transducer in vertebrate hypoxic vasoconstriction and hypoxic vasodilation," Journal of Experimental Biology, vol. 209, no. 20, pp. 4011-4023, 2006.

[48] V. Telezhkin, S. P. Brazier, S. H. Cayzac, W. J. Wilkinson, D. Riccardi, and P. J. Kemp, "Mechanism of inhibition by hydrogen 
sulfide of native and recombinant BKCa channels," Respiratory Physiology and Neurobiology, vol. 172, no. 3, pp. 169-178, 2010.

[49] N. R. Prabhakar, "Hydrogen sulfide $\left(\mathrm{H}_{2} \mathrm{~S}\right)$ : a physiologic mediator of carotid body response to hypoxia," Advances in Experimental Medicine and Biology, vol. 758, pp. 109-113, 2012.

[50] S. Donzelli, M. G. Espey, W. Flores-Santana et al., "Generation of nitroxyl by heme protein-mediated peroxidation of hydroxylamine but not N-hydroxy-L-arginine," Free Radical Biology and Medicine, vol. 45, no. 5, pp. 578-584, 2008.

[51] R. Schwarcz, T. Eid, and F. Du, "Neurons in layer III of the entorhinal cortex. A role in epileptogenesis and epilepsy?" Annals of the New York Academy of Sciences, vol. 911, pp. 328$342,2000$.

[52] M. C. McKenna, H. S. Waagepetersen, A. Schousboe, and U. Sonnewald, "Neuronal and astrocytic shuttle mechanisms for cytosolic-mitochondrial transfer of reducing equivalents: Current evidence and pharmacological tools," Biochemical Pharmacology, vol. 71, no. 4, pp. 399-407, 2006.

[53] T. Shintani, T. Iwabuchi, T. Soga et al., "Cystathionine betasynthase as a carbon monoxide-sensitive regulator of bile excretion," Hepatology, vol. 49, no. 1, pp. 141-150, 2009.

[54] T. Morikawa, M. Kajimura, T. Nakamura et al., "Hypoxic regulation of the cerebral microcirculation is mediated by a carbon monoxide-sensitive hydrogen sulfide pathway," Proceedings of the National Academy of Sciences of the United States of America, vol. 109, no. 4, pp. 1293-1298, 2012.

[55] K. J. Buckler, "Effects of exogenous hydrogen sulphide on calcium signalling, background (TASK) K channel activity and mitochondrial function in chemoreceptor cells," Pflugers Archiv European Journal of Physiology, vol. 463, no. 5, pp. 743-754, 2012.

[56] V. V. Makarenko, J. Nanduri, G. Raghuraman et al., "Endogenous $\mathrm{H}_{2} \mathrm{~S}$ is required for hypoxic sensing by carotid body glomus cells," The American Journal of Physiology-Cell Physiology, vol. 303, no. 9, pp. C916-C923, 2012.

[57] Y. Nagai, M. Tsugane, J.-I. Oka, and H. Kimura, "Hydrogen sulfide induces calcium waves in astrocytes," The FASEB Journal, vol. 18, no. 3, pp. 557-559, 2004.

[58] M. A. García-Bereguiaín, A. K. Samhan-Arias, F. J. MartínRomero, and C. Gutiérrez-Merino, "Hydrogen sulfide raises cytosolic calcium in neurons through activation of L-type $\mathrm{Ca}^{2+}$ channels," Antioxidants and Redox Signaling, vol. 10, no. 1, pp. 31-41, 2008.

[59] A. Kawabata, T. Ishiki, K. Nagasawa et al., "Hydrogen sulfide as a novel nociceptive messenger," Pain, vol. 132, no. 1-2, pp. 74-81, 2007.

[60] M. Matsunami, T. Tarui, K. Mitani et al., "Luminal hydrogen sulfide plays a pronociceptive role in mouse colon," Gut, vol. 58, no. 6, pp. 751-761, 2009.

[61] Y. Maeda, Y. Aoki, F. Sekiguchi et al., "Hyperalgesia induced by spinal and peripheral hydrogen sulfide: evidence for involvement of Cav3.2 T-type calcium channels," Pain, vol. 142, no. 1-2, pp. 127-132, 2009.

[62] V. V. Makarenko, Y. J. Peng, G. Yuan et al., "CaV3.2 T-type $\mathrm{Ca}^{2+}$ channels in $\mathrm{H}_{2} \mathrm{~S}$-mediated hypoxic response of the carotid body," The American Journal of Physiology-Cell Physiology, vol. 308, no. 2, pp. C146-C154, 2015.

[63] L. He, B. Dinger, C. Gonzalez, A. Obeso, and S. Fidone, "Function of NADPH oxidase and signaling by reactive oxygen species in rat carotid body type I cells," in The Arterial Chemoreceptors, vol. 580 of Advances in Experimental Medicine and Biology, pp. 155-160, 2006.
[64] N. R. Prabhakar, "Sensory plasticity of the carotid body: role of reactive oxygen species and physiological significance," Respiratory Physiology \& Neurobiology, vol. 178, no. 3, pp. 375380, 2011.

[65] R. S. Fitzgerald, M. Shirahata, I. Chang, and E. Kostuk, "The impact of hypoxia and low glucose on the release of acetylcholine and ATP from the incubated cat carotid body," Brain Research, vol. 1270, pp. 39-44, 2009.

[66] C. Alcayaga, R. Varas, V. Valdés et al., "ATP- and ACh-induced responses in isolated cat petrosal ganglion neurons," Brain Research, vol. 1131, no. 1, pp. 60-67, 2007.

[67] S. E. J. Williams, P. Wootton, H. S. Mason et al., "Hemoxygenase-2 is an oxygen sensor for a calcium-sensitive potassium channel," Science, vol. 306, no. 5704, pp. 2093-2097, 2004.

[68] K. P. Strohl, A. J. Thomas, P. St. Jean, E. H. Schlenker, R. J. Koletsky, and N. J. Schork, "Ventilation and metabolism among rat strains," Journal of Applied Physiology, vol. 82, no. 1, pp. 317323, 1997.

[69] L. F. Hayward, M. Castellanos, and C. Noah, "Cardiorespiratory variability following repeat acute hypoxia in the conscious SHR versus two normotensive rat strains," Autonomic Neuroscience: Basic and Clinical, vol. 171, no. 1-2, pp. 58-65, 2012.

[70] Z. Y. Tan, Y. Lu, C. A. Whiteis et al., "Chemoreceptor hypersensitivity, sympathetic excitation, and overexpression of ASIC and TASK channels before the onset of hypertension in SHR," Circulation Research, vol. 106, no. 3, pp. 536-545, 2010.

[71] P. Kumar and N. R. Prabhakar, "Peripheral chemoreceptors: function and plasticity of the carotid body," Comprehensive Physiology, vol. 2, no. 1, pp. 141-219, 2012.

[72] D. D. Kline, Y.-J. Peng, D. J. Manalo, G. L. Semenza, and N. R. Prabhakar, "Defective carotid body function and impaired ventilatory responses to chronic hypoxia in mice partially deficient for hypoxia-inducible factor lalpha," Proceedings of the National Academy of Sciences of the United States of America, vol. 99, no. 2, pp. 821-826, 2002.

[73] Y. J. Peng, J. Nanduri, S. A. Khan et al., "Hypoxia-inducible factor 2alpha (HIF-2alpha) heterozygous-null mice exhibit exaggerated carotid body sensitivity to hypoxia, breathing instability, and hypertension," Proceedings of the National Academy of Sciences of the United States of America, vol. 108, no. 7, pp. 30653070, 2011.

[74] Z. Altaany, Y. Ju, G. Yang, and R. Wang, "The coordination of S-sulfhydration, S-nitrosylation, and phosphorylation of endothelial nitric oxide synthase by hydrogen sulfide," Science Signaling, vol. 7, no. 342, pp. ra87-ra87, 2014.

[75] K. Zhao, Y. Ju, S. Li, Z. Altaany, R. Wang, and G. Yang, "Ssulfhydration of MEK1 leads to PARP-1 activation and DNA damage repair," EMBO Reports, vol. 15, no. 7, pp. 792-800, 2014.

[76] M. M. Gadalla and S. H. Snyder, "Hydrogen sulfide as a gasotransmitter," Journal of Neurochemistry, vol. 113, no. 1, pp. 14-26, 2010.

[77] D. Stubbert, O. Prysyazhna, O. Rudyk, J. Scotcher, J. R. Burgoyne, and P. Eaton, "Protein kinase G I $\alpha$ oxidation paradoxically underlies blood pressure lowering by the reductant hydrogen sulfide," Hypertension, vol. 64, no. 6, pp. 1344-1351, 2014. 


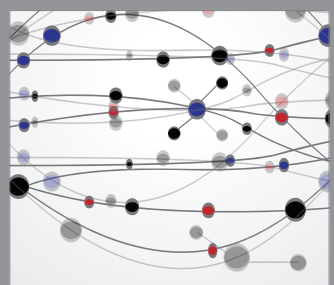

The Scientific World Journal
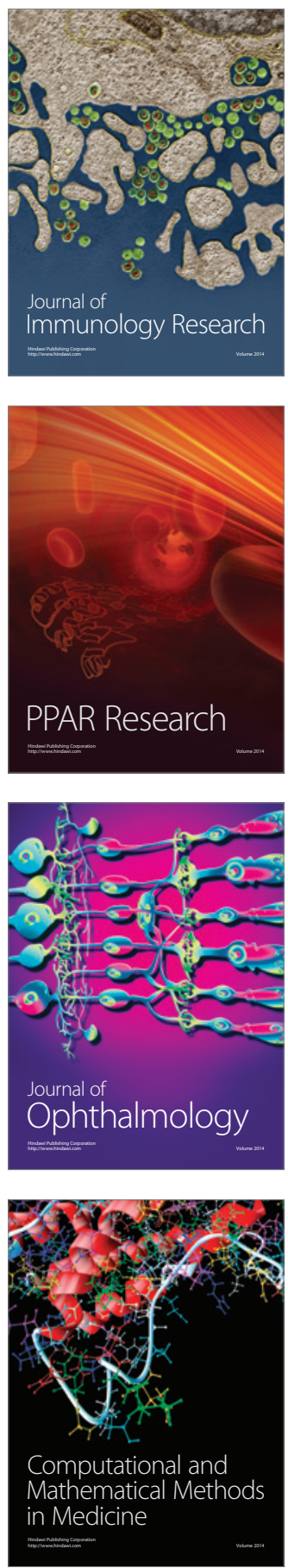

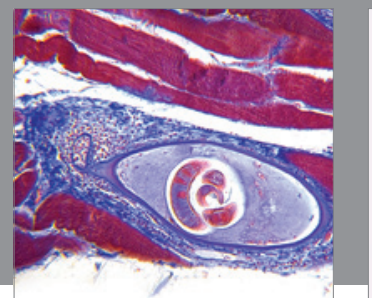

Gastroenterology

Research and Practice
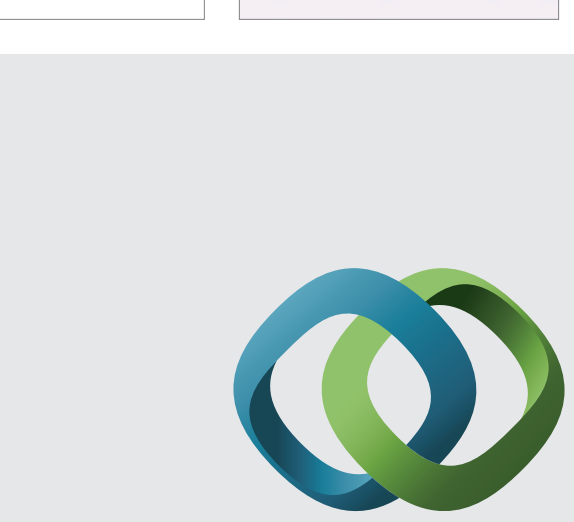

\section{Hindawi}

Submit your manuscripts at

http://www.hindawi.com
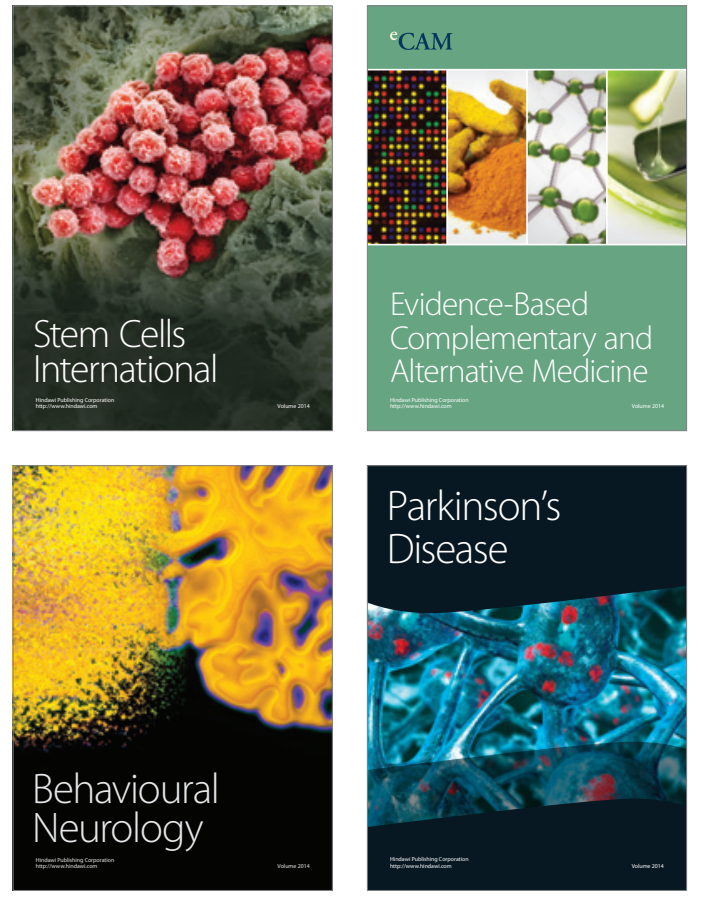
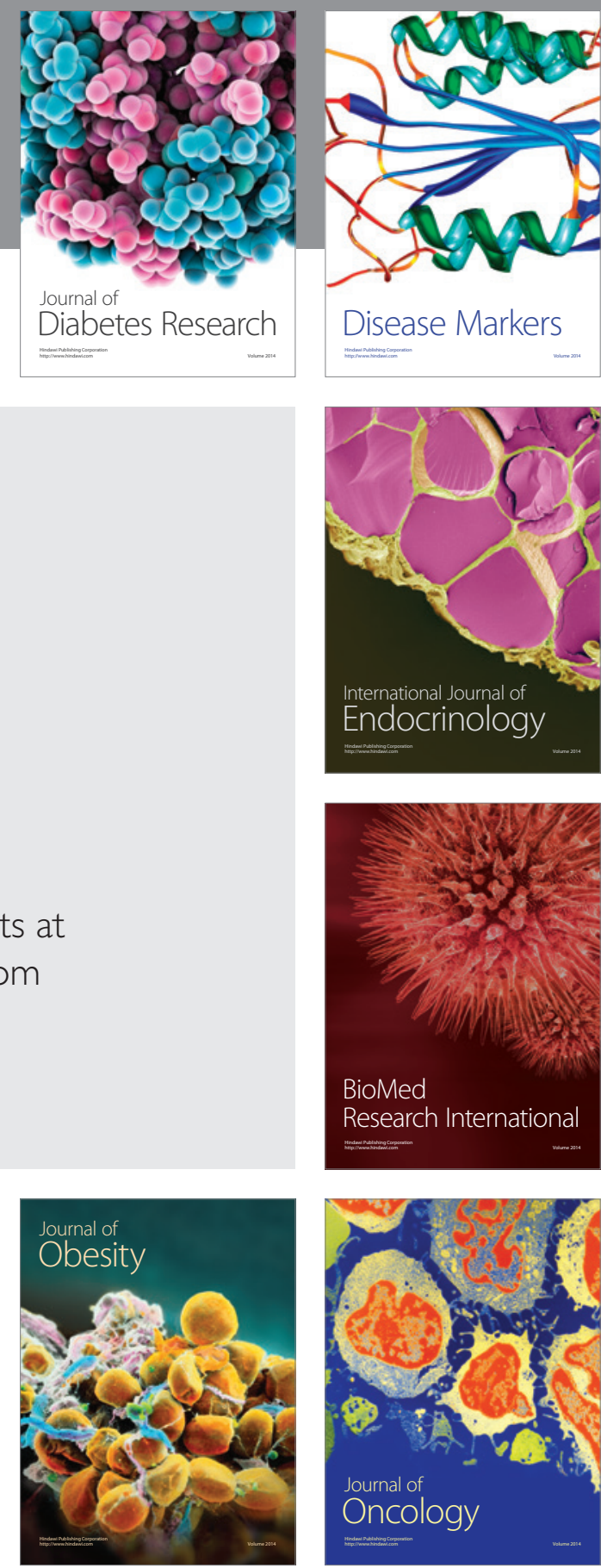

Disease Markers
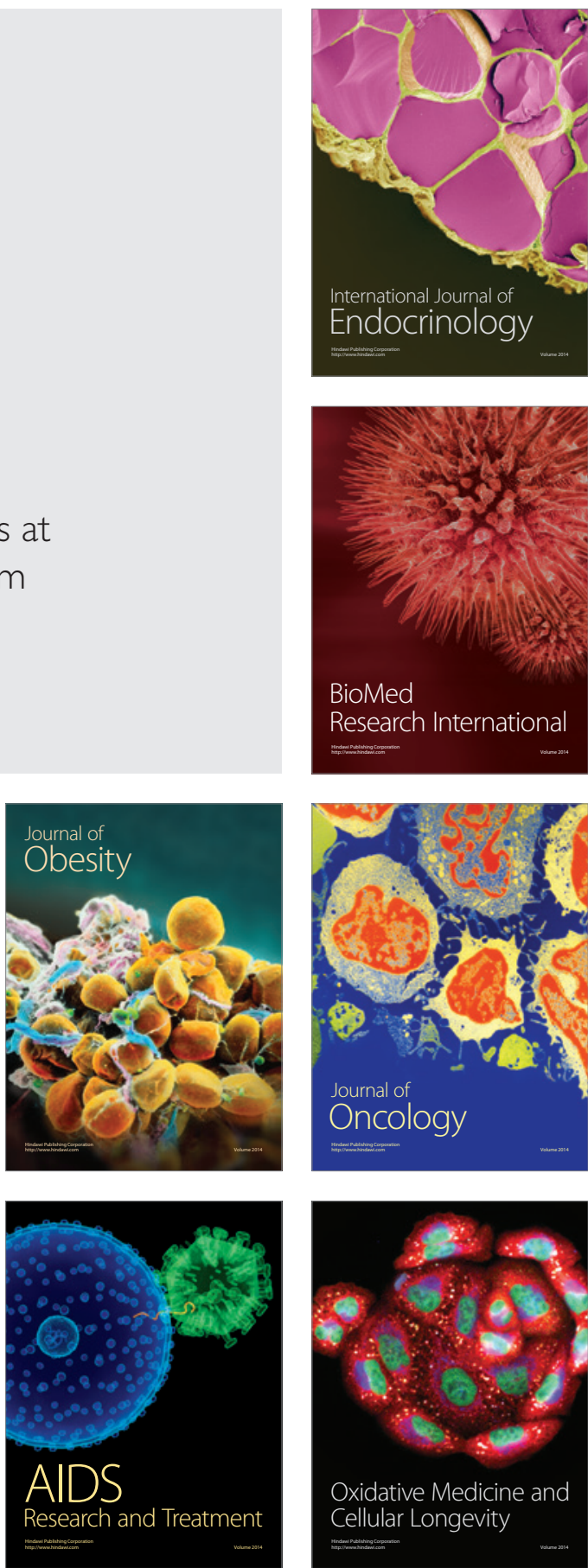